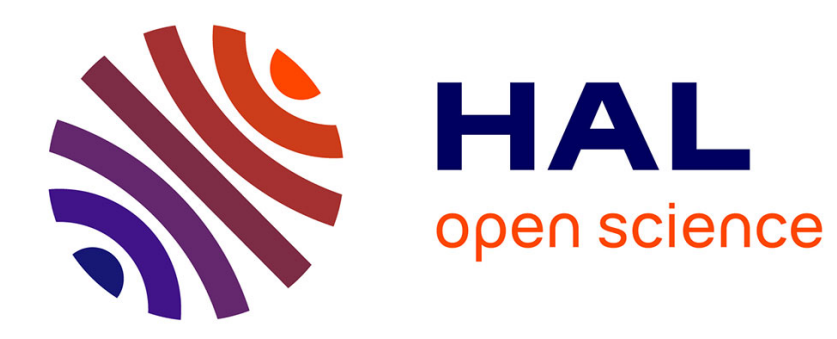

\title{
Oxidation behavior of titanium aluminides
}

G. Meier, F. Pettit, S. Hu

\section{To cite this version:}

G. Meier, F. Pettit, S. Hu. Oxidation behavior of titanium aluminides. Journal de Physique IV Proceedings, 1993, 03 (C9), pp.C9-395-C9-402. 10.1051/jp4:1993941 . jpa-00252381

\section{HAL Id: jpa-00252381 https://hal.science/jpa-00252381}

Submitted on 1 Jan 1993

HAL is a multi-disciplinary open access archive for the deposit and dissemination of scientific research documents, whether they are published or not. The documents may come from teaching and research institutions in France or abroad, or from public or private research centers.
L'archive ouverte pluridisciplinaire HAL, est destinée au dépôt et à la diffusion de documents scientifiques de niveau recherche, publiés ou non, émanant des établissements d'enseignement et de recherche français ou étrangers, des laboratoires publics ou privés. 


\title{
Oxidation behavior of titanium aluminides
}

\author{
G.H. Meier $\left({ }^{1}\right)$, F.S. Pettit $\left({ }^{1}\right)$ and S. Hu $\left({ }^{2}\right)$ \\ (1) University of Pittsburgh, Pittsburgh, PA 15261, U.S.A. \\ $\left(^{2}\right)$ Lockheed Palo Alto Research Laboratory, Palo Alto, CA 94304, U.S.A.
}

\begin{abstract}
Results from an ongoing study of the high temperature oxidation of intermetallic compounds in the Ti-Al system are presented. The oxidation behavior of alloys based on TiAl $(\gamma)$ has been found to be extremely complex depending on temperature and atmosphere composition. Protective alumina scales are formed in pure $\mathrm{O}_{2}$ up to a critical temperature above which a mixed $\mathrm{TiO}_{2} / \mathrm{Al}_{2} \mathrm{O}_{3}$ scale forms and grows at rates which are orders-of-magnitude faster than that of alumina. This phenomenon is believed to result from the formation of Al-containing internal oxides which coupled with the closeness in stability of alumina and the titanium oxides, prevents the alumina from becoming continuous. Continuous alumina scales were not observed, even at temperatures below $1000^{\circ} \mathrm{C}$, when $\mathrm{N}_{2}$ was present in the oxidizing gas. The effect of the $\mathrm{N}_{2}$ has been shown to be involved with the initial development of the reaction products.
\end{abstract}

\section{Introduction.}

Alloys in the Ti-Al system are of interest for high temperature systems such as aircraft engines because they have low density and substantial high temperature strengths. However, their resistance to oxidation and interstitial embrittlement is a concern. Those alloys which form alumina scales have excellent resistance while those which form titania-rich scales oxidize at rates which are unacceptably fast for most applications. The alloys based on $\gamma-\mathrm{TiAl}$ are generally regarded as having better oxidation resistance than those based on $\alpha_{2}-\mathrm{Ti}_{3} \mathrm{Al}$. The oxidation behavior of $\gamma$ is the subject of this paper.

OXIDATION OF $\gamma$-TiAl. - Choudhury et al. [1] studied the oxidation of TiAl (50 at\% Al) in $\mathrm{O}_{2}$ and air over the temperature range $800-1200^{\circ} \mathrm{C}$. In $\mathrm{O}_{2}$ cast TiAl which was abraded through 120 grit $\mathrm{SiC}$ formed alumina and exhibited $k_{\mathrm{p}}$ values $\approx 10^{-9} \mathrm{~g}^{2} \mathrm{~cm}^{-4} \mathrm{~h}^{-1}$ at $950{ }^{\circ} \mathrm{C}$ but polished specimens formed $\mathrm{TiO}_{2}$-rich scales and exhibited $k_{\mathrm{p}}$ values of about $10^{-5}$ to $10^{-6} \mathrm{~g}^{2} \mathrm{~cm}^{-4} \mathrm{~h}^{-1}$. A Ti $\mathrm{T}_{3} \mathrm{Al}$ layer formed between the oxide and the alloy. Extruded TiAl formed alumina scales regardless of surface preparation. Choudhury $e t$ al. explained these differences in terms of macroinhomogeneities in the cast structure. Oxidation behavior in air at $950{ }^{\circ} \mathrm{C}$ was independent of specimen preparation or fabrication method with titaniaforming kinetics $\left(k_{\mathrm{p}}\right.$ about $\left.10^{-5}-10^{-6} \mathrm{~g}^{2} \mathrm{~cm}^{-4} \mathrm{~h}^{-1}\right)$ observed in all cases. The scales were similar to those formed on polished specimens in $\mathrm{O}_{2}$ at $950^{\circ} \mathrm{C}$. Oxidation kinetics for all alloys, regardless of surface preparation, at 1100 and $1200^{\circ} \mathrm{C}$ indicated $\mathrm{TiO}_{2}$ formation. The transition from titania to alumina forming kinetics with decreasing temperature occurred at a higher temperature in $\mathrm{O}_{2}$ with internal oxidation at the two higher temperatures. Experiments to determine the species responsible for the difference between exposure in $\mathrm{O}_{2}$ and air indicated that $\mathrm{CO}, \mathrm{CO}_{2}$ and $\mathrm{H}_{2} \mathrm{O}$ impurities were not responsible nor was the difference 
in $p_{0_{2}}$. It was concluded that $\mathrm{N}_{2}$ was responsible for the increased rate of oxidation in air although no $\mathrm{N}_{2}$-containing phases were identified in the scale or substrate. Several mechanisms were postulated including:

1) $\mathrm{N}_{2}$ doping of an initial $\mathrm{TiO}_{2}$ scale resulting in more rapid oxygen transport to the scale/ $\mathrm{Ti}_{3} \mathrm{Al}$ interface;

2) The grain boundary diffusion of $\mathrm{N}_{2}$ through the oxide to form AlN or possibly AlON at the scale/Ti 3 Al interface;

3) $\mathrm{N}_{2}$ grain boundary diffusion through the scale to the scale/ $\mathrm{Ti}_{3} \mathrm{Al}$ interface with a subsequent stabilization of the $\mathrm{Ti}_{3} \mathrm{Al}$ layer with the reduced $\mathrm{Al}$ activity at the interface promoting the growth of $\mathrm{TiO}_{2}$.

Mendiratta and Choudhury [2] reported that varying the Al-content of TiAl (50, 53, and 54 at \%) did not affect the oxidation behavior. Appalonia et al. [3, 4], however found that:

1) Alloys containing 50,53 , and 56 at $\% \mathrm{Al}$ formed continuous alumina in oxygen at $800^{\circ} \mathrm{C}$ with the Ti-56 at\% Al alloy continuing this behavior up to $1000{ }^{\circ} \mathrm{C}$. Between 1000 and $1100{ }^{\circ} \mathrm{C}$, however, $k_{\mathrm{p}}$ increased by a factor of $10^{6}$ for the 56 at $\% \mathrm{Al}$ alloy as the result of a transition from alumina to titania formation;

2) Alloys containing 50,53, and 56 at\% $\mathrm{Al}$ underwent accelerated oxidation in air with the rate independent of $\mathrm{Al}$ content at $800^{\circ} \mathrm{C}$.

\section{Experimental.}

Arc-melted Ti-Al alloys with Al contents of 52 and 54 at\% $(\gamma)$ were studied. No substantial effect of heat treatment was observed on the oxidation behavior. Therefore, the data will be presented without specifying heat treatment. All specimens were polished through 600 grit SiC. Oxidation experiments were carried out in pure $\mathrm{O}_{2}$, air, tank argon containing $\mathrm{O}_{2}$ impurities at $p_{0_{2}} \approx 10^{-4} \mathrm{~atm}$, and various $\mathrm{O}_{2}-\mathrm{N}_{2}$ mixtures at temperatures from 750 to $1100{ }^{\circ} \mathrm{C}$. The oxidation kinetics were studied using a Cahn Model 2000 microbalance and the oxidation morphologies were studied using x-ray diffraction (XRD), Auger electron spectroscopy (AES), scanning electron microscopy, and energy-and wavelength dispersive $x$ ray analysis (EDS and WDS).

\section{Results and discussion.}

3.1 THERMODYNAMICS. - An important aspect of the oxidation of Ti-Al alloys is the small difference in standard free energy of formation between alumina and the oxides of titanium which is accentuated by the negative deviation from ideal solution behavior in the Ti-Al system. This is illustrated in figure 1 which is a plot of estimated activities versus composition in titanium-aluminum alloys at $1100 \mathrm{~K}$. The aluminum activity is much smaller than unity in $\mathrm{Ti}_{3} \mathrm{Al}$ and $\mathrm{TiAl}$. In fact, combining these activities with standard free energy data for the oxides indicates that $\mathrm{TiO}$ is more stable in contact with the alloy than is $\mathrm{Al}_{2} \mathrm{O}_{3}$ for atom fractions of $\mathrm{Al}$ less than about 0.5 . More detailed analyses of this situation are presented by Rahmel and Spencer [6] and Luthra [7]. Thus, $\mathrm{Al}_{2} \mathrm{O}_{3}$ is unstable in contact with binary $\alpha_{2}$ and is only marginally more stable than TiO in contact with $\gamma$.

3.2 EFFECTS OF TEMPERATURE. - Weight change data for TiAl are compared in figure 2 for exposures in air and in $\mathrm{O}_{2}$ at a number of temperatures. In both atmospheres the weight gains are low at lower temperatures and then increase drastically over a narrow range of 

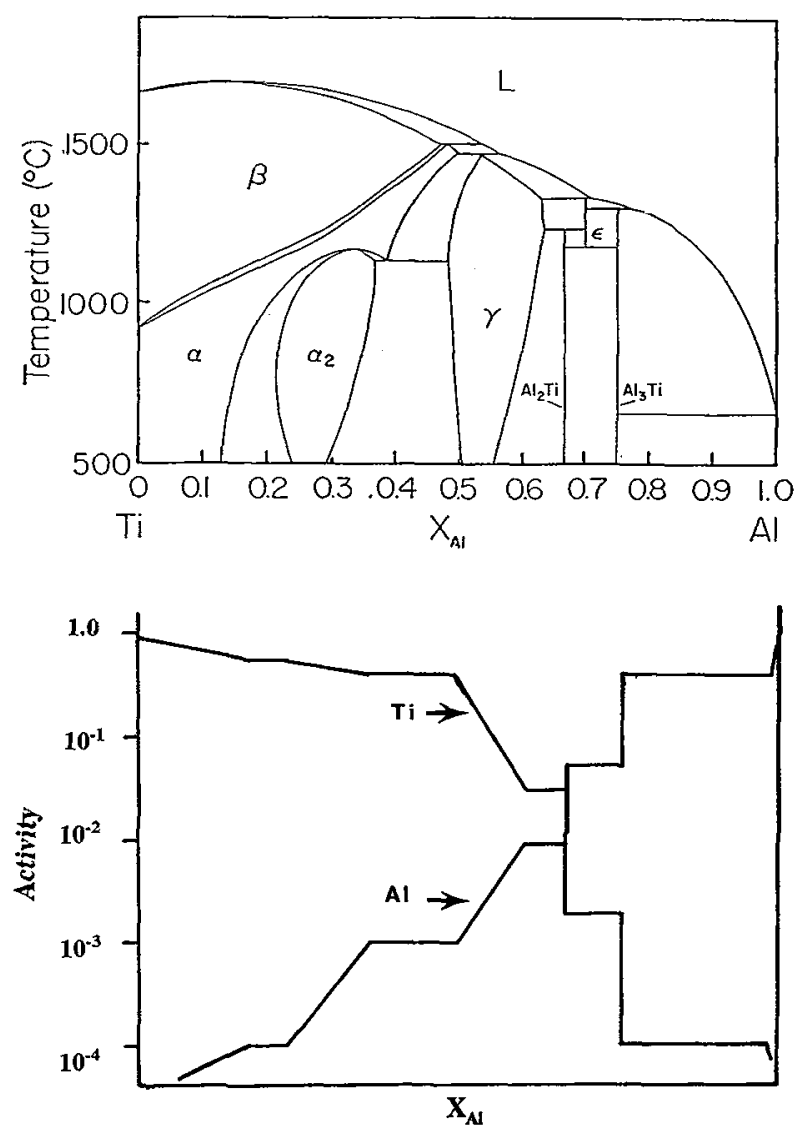

Fig. 1. - Binary phase diagram for the Ti-Al system (Ref. [5]) and estimated aluminum activities versus atom fraction of aluminum at $1100 \mathrm{~K}$.

temperatures. In $\mathrm{O}_{2}$, at temperatures of $1000^{\circ} \mathrm{C}$ and lower, a thin alumina scale (Fig. 3a) develops and the oxidation rates are correspondingly slow. However, on raising the temperature by only $25^{\circ} \mathrm{C}$ the rate increases markedly as a result of the development of the oxidation morphology illustrated in figures $3 \mathrm{~b}, \mathrm{c}, \mathrm{d}$. The scale consists of an outer rutile layer over a layer which is an intimate mixture of rutile and alumina. An internal oxidation zone is observed below the scale. The cause of the transition is not completely understood but may well be associated with the internal oxides which are not observed at temperatures below $1000^{\circ} \mathrm{C}$, even when the alumina is not continuous. The internal oxides are indicated by EDS to contain both $\mathrm{Al}$ and $\mathrm{Ti}$ which suggests they are $\mathrm{TiAl}_{2} \mathrm{O}_{5}$. This oxide cannot form below the eutectoid temperature in the $\mathrm{TiO}_{2}-\mathrm{Al}_{2} \mathrm{O}_{3}$ system which is reported to be $1010^{\circ} \mathrm{C}$ [6]. At lower temperatures internal oxidation is not possible because $\mathrm{Al}_{2} \mathrm{O}_{3}$ would have to form and it is likely that the $\mathrm{Al}$ activity would not be high enough for this phase to form. The formation of internal $\mathrm{TiAl}_{2} \mathrm{O}_{5}$ would deplete the alloy of $\mathrm{Al}$ since two moles of $\mathrm{Al}$ react for each mole of $\mathrm{Ti}$. Therefore, since the alumina is only marginally more stable than $\mathrm{TiO}$, the internal oxidation would prevent an alumina scale from forming. Further experiments are needed to ascertain if the above mechanism is correct or if the internal oxidation is in fact the result. rather than the cause, of a continuous alumina scale not forming. 


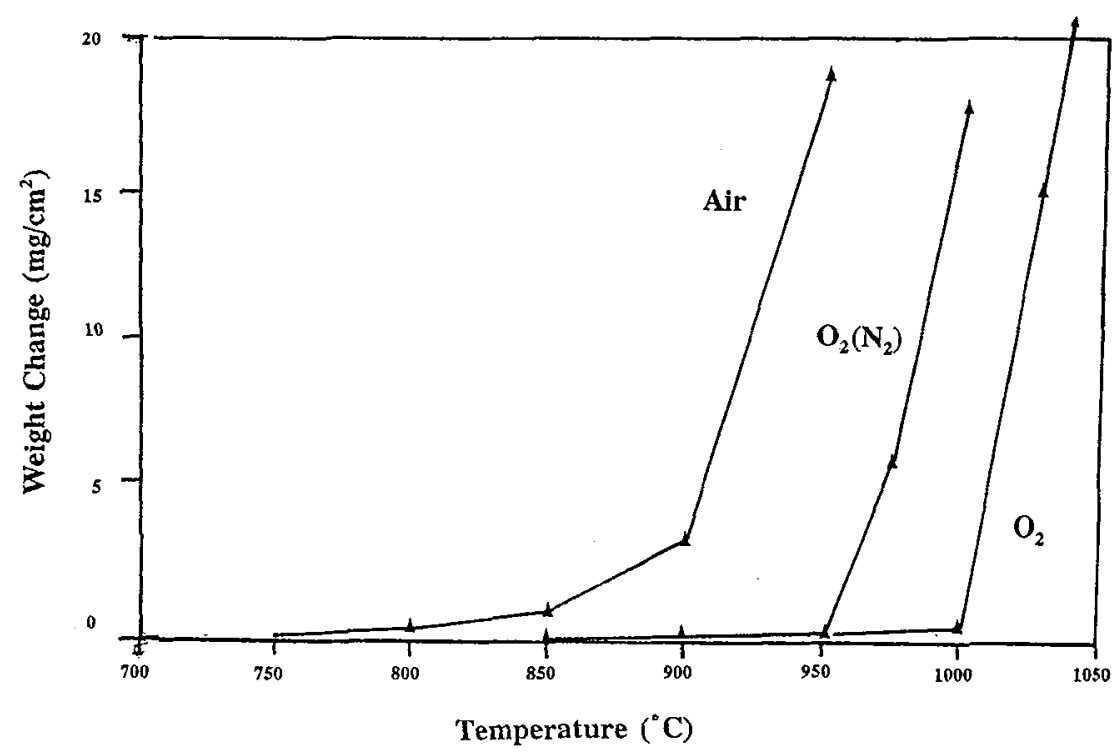

Fig. 2. - Weight change versus temperature for TiAl oxidized for 58 hours in air, oxygen, and oxygen which is contaminated with a small amount of nitrogen. Air and $\mathrm{O}_{2}\left(\mathrm{~N}_{2}\right)$ curves are for 54 at $\% \mathrm{Al}$ and $\mathrm{O}_{2}$ curve is for 52 at\% $\mathrm{Al}$.

3.3 EFfECTS OF ATMOSPHERE. - Protective alumina scales form on TiAl, exposed in $\mathrm{O}_{2}$, up to $1000^{\circ} \mathrm{C}$ (Fig. 2). However, the same exposures conducted in air result in the formation of $\mathrm{TiO}_{2}$-rich scales which grow at rates orders of magnitude faster than pure alumina scales and even trace amounts of $\mathrm{N}_{2}$ lower the critical temperature for the transition from alumina to titania formation, as indicated by the line labelled $\mathrm{O}_{2}\left(\mathrm{~N}_{2}\right)$ in figure 2. This effect is illustrated in figure 4. The rate of oxidation increases continually as increasing amounts of $\mathrm{N}_{2}$ are added to pure $\mathrm{O}_{2}$. Figure 5 shows that addition of $10 \% \mathrm{~N}_{2}$ to $\mathrm{O}_{2}$ results in the formation of nodules of intermixed $\mathrm{TiO}_{2}$ and $\mathrm{Al}_{2} \mathrm{O}_{3}$ interspersed with thin areas of protective $\mathrm{Al}_{2} \mathrm{O}_{3}$ which would cover the entire surface in the absence of $\mathrm{N}_{2}$. The area density of these nodules increases as the concentration of $\mathrm{N}_{2}$ increases (Fig. 6) until the surface is completely covered with the mixed oxides when the gas contains $90 \% \mathrm{~N}_{2}$. The effect of $\mathrm{N}_{2}$ appears to involve the nucleation and initial growth of the scale since preoxidation in argon, which contains $\mathrm{O}_{2}$ impurities, develops an alumina scale which remains protective during subsequent exposures in air (Fig. 7). Kobayashi, et al. [8] have also reported that preformed alumina scales formed on TiAl at reduced $\mathrm{O}_{2}$ pressure remain protective during subsequent exposures in air, even under cyclic conditions.

The influence of $\mathrm{N}_{2}$ on the initial scale development has been investigated using Auger spectra collected while sputtering through scales formed for short times in $\mathrm{O}_{2}$ and air. The results are summarized in figure 8 . The scales on specimens which were cooled as soon as they reached $900^{\circ} \mathrm{C}(0 \mathrm{~min})$ were $2000-3000 \AA$ thick with AES profiles which were consistent with intermixed transient oxides of $\mathrm{Al}$ and $\mathrm{Ti}$. However, specimens exposed in air were found to have a $\mathrm{N}_{2}$-rich layer at the scale/alloy interface. This layer is indicated as TiN in figure 8 but is still to be unequivocally identified. The scales on specimens which were held in $\mathrm{O}_{2}$ at $900^{\circ} \mathrm{C}$ for 15 minutes were quite different from those in air. The AES profiles indicated that a continuous layer of aluminum oxide was forming below the mixed transient oxide in 

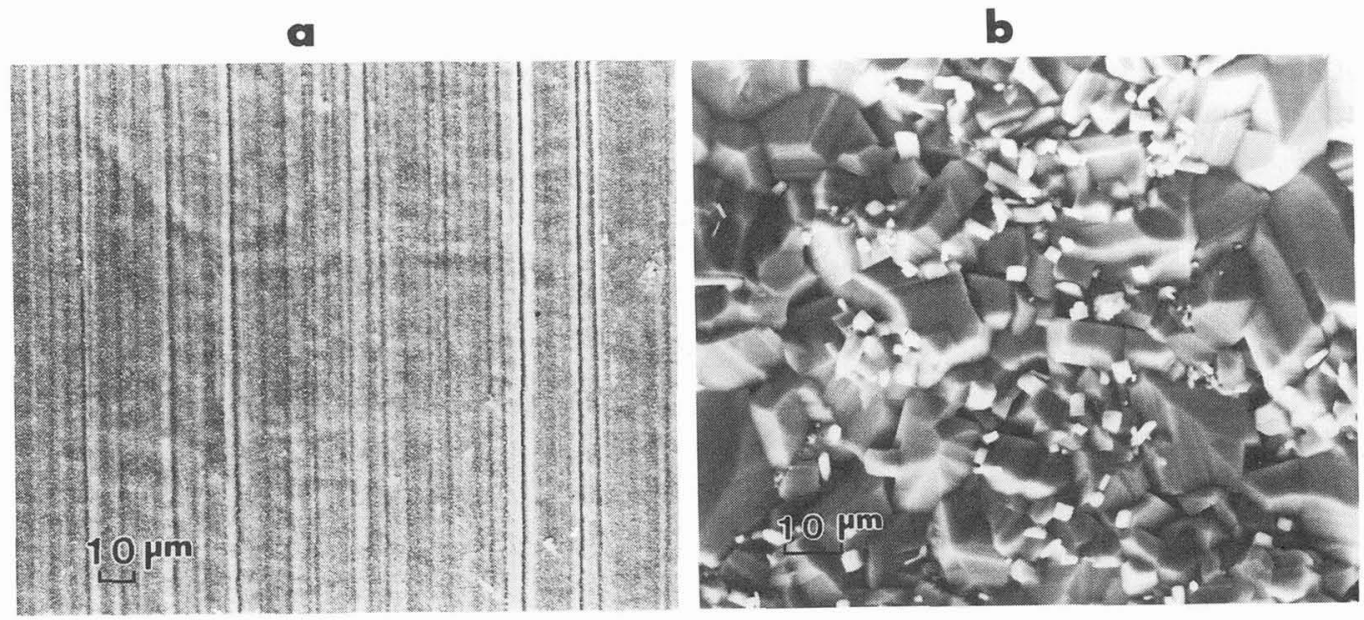

Scale/Alloy Interface
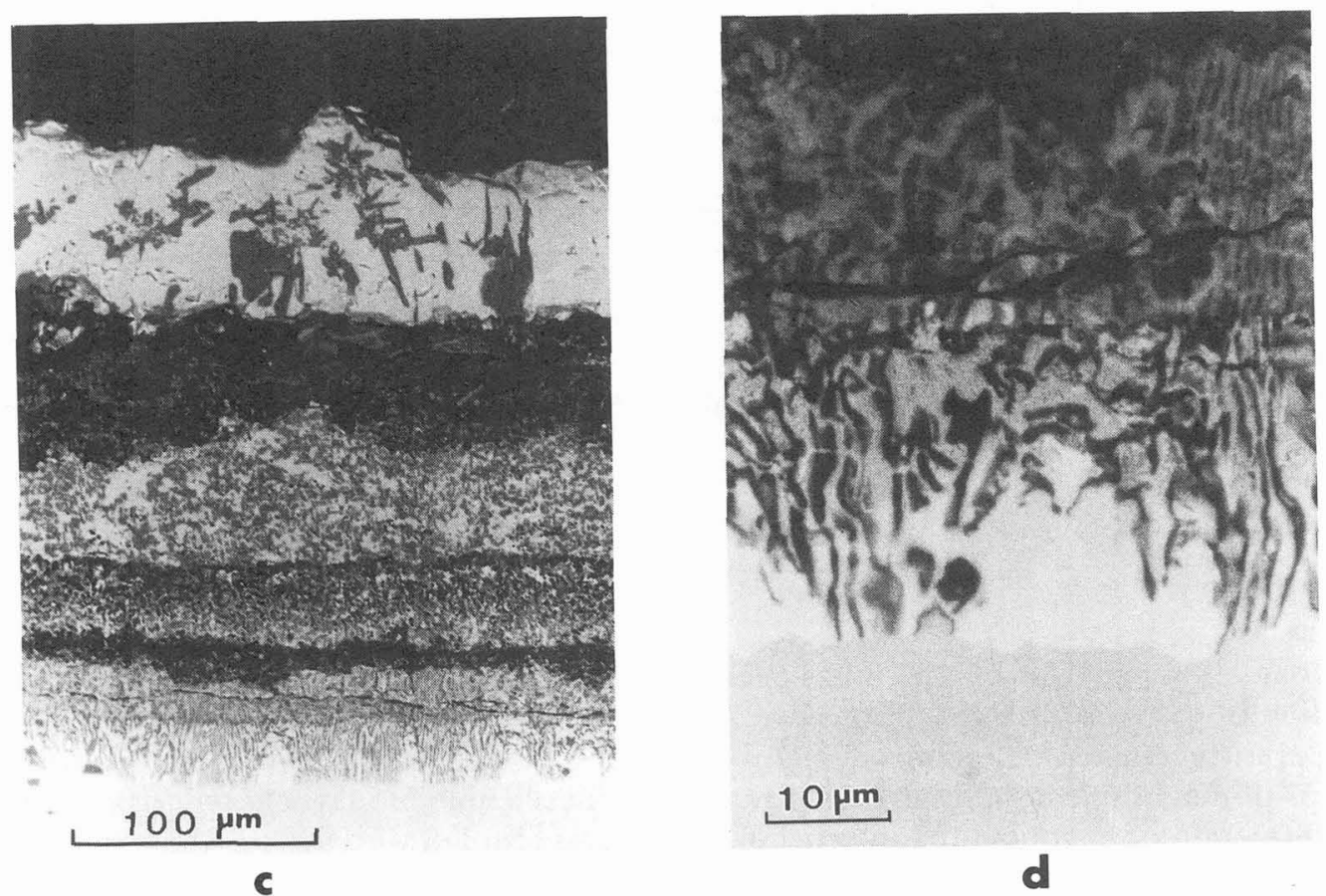

Fig. 3. - Surfaces and cross-sections of TiAl (52 at $\%$ ) oxidized for 160 hours in oxygen: a) surface, $900^{\circ} \mathrm{C}$; b) surface, $1050^{\circ} \mathrm{C}$; c) and d) cross-section, $1050^{\circ} \mathrm{C}$.

$\mathrm{O}_{2}$ while in air the scale consisted only of intermixed $\mathrm{Ti}$ - and $\mathrm{Al}$-oxides and was almost ten times as thick as that in $\mathrm{O}_{2}$. Therefore, it appears that a major effect of the $\mathrm{N}_{2}$ is in forming a nitride layer which prevents alumina from developing continuity. However, the presence 
of the $\mathrm{N}_{2}$ is also required for the continued rapid growth of the scale since figure 7 indicates that switching the gas to $\mathrm{O}_{2}$ after a one hour exposure in air caused the oxidation rate to decrease markedly.

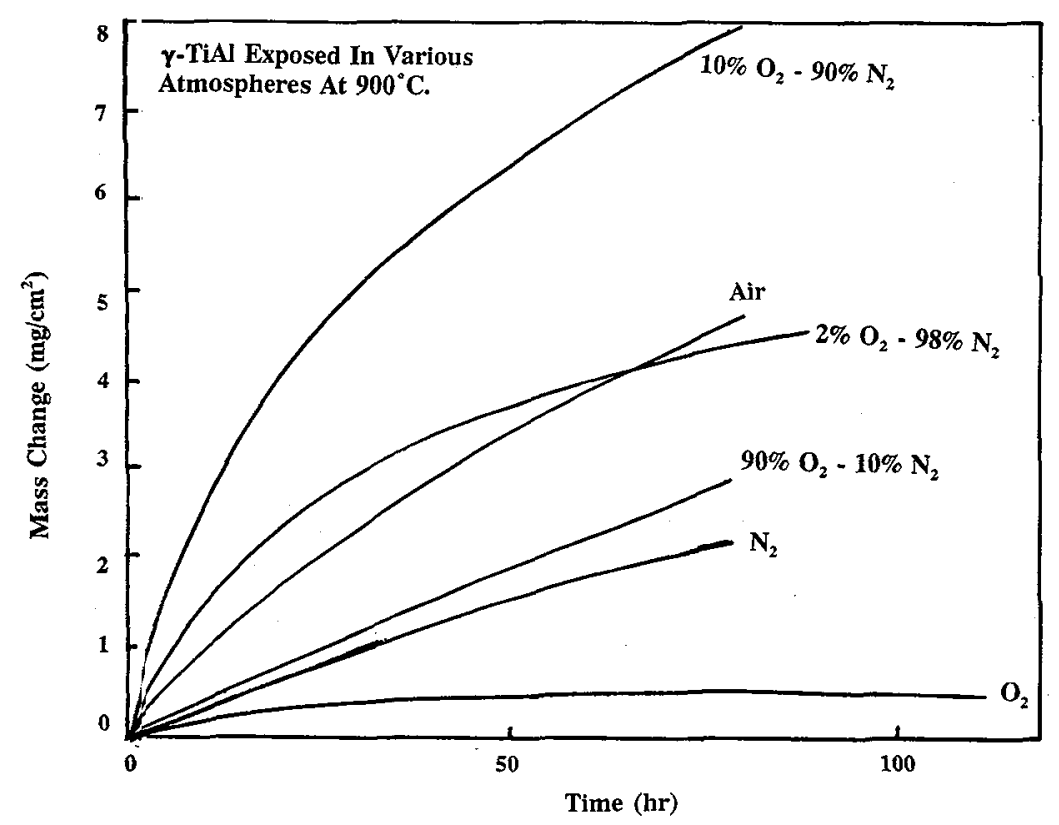

Fig. 4. - Weight change versus time data for $\mathrm{TiAl}(52$ at $\% \mathrm{Al})$ oxidized at $900^{\circ} \mathrm{C}$ in various atmospheres.

\section{Summary.}

The oxidation behavior of $\gamma$-TiAl has been found to depend on temperature and the composition of the oxidizing gas. Protective alumina scales formed in pure $\mathrm{O}_{2}$ up to a critical temperature above which a mixed $\mathrm{TiO}_{2} / \mathrm{Al}_{2} \mathrm{O}_{3}$ scale formed which grew at rates which are orders-of-magnitude faster than that of alumina. This phenomenon is believed to result from the formation of Al-containing internal oxides which, coupled with the closeness in stability of alumina and the titanium oxides, prevented the alumina from becoming continuous. Continuous alumina scales did not form at any temperature above $750{ }^{\circ} \mathrm{C}$ when $\mathrm{N}_{2}$ was present in the oxidizing gas. The effect of the $\mathrm{N}_{2}$ has been shown to be involved with the initial development of the reaction products.

\section{References}

[1] Choudhury N.S., Graham H.C., Hinze J.W., Properties of High Temperature Alloys, Z.A. Foroulis, F.S. Pettit Eds. (The Electrochem. Soc., 1976) p. 668. 
[2] Mendiratta M.G., Choudhury N.S., Properties and Microstructure of HighTemperature Materials, AFML-TR-78-112, Contract No. F33615-75-C-1005, (Systems Research Laboratories, Inc. Ohio, August 1978).

[3] APPOLONIA D.S., The Oxidation of Gamma-Titanium Aluminides, Bachelor of Science Thesis, University of Pittsburgh (Pittsburgh, PA, 1988).

[4] Meier G.H., Appalonia D., Perkins R.A., Chiang K.T., Oxidation of HighTemperature Intermetallics, T. Grobstein, J. Doychak Eds. (TMS, 1989) p. 185.

[5] Mishurda J.C., Perepezko J.H., Private Communication (1991).

[6] RAHMEl A., SPENCER P.J., Oxid. Met. 35 (1991) 53.

[7] Luthra K.L., Oxid. Met. 36 (1991) 475.

[8] Kobayashi E., Yoshihara M., Tanaka R., High Temp. Tech. 8 (1990) 179.
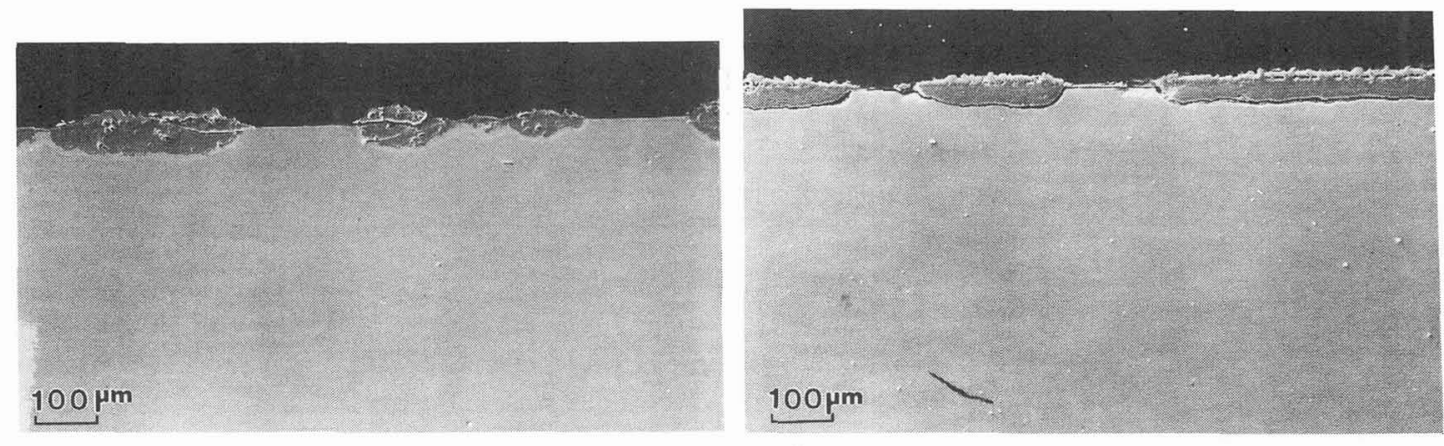

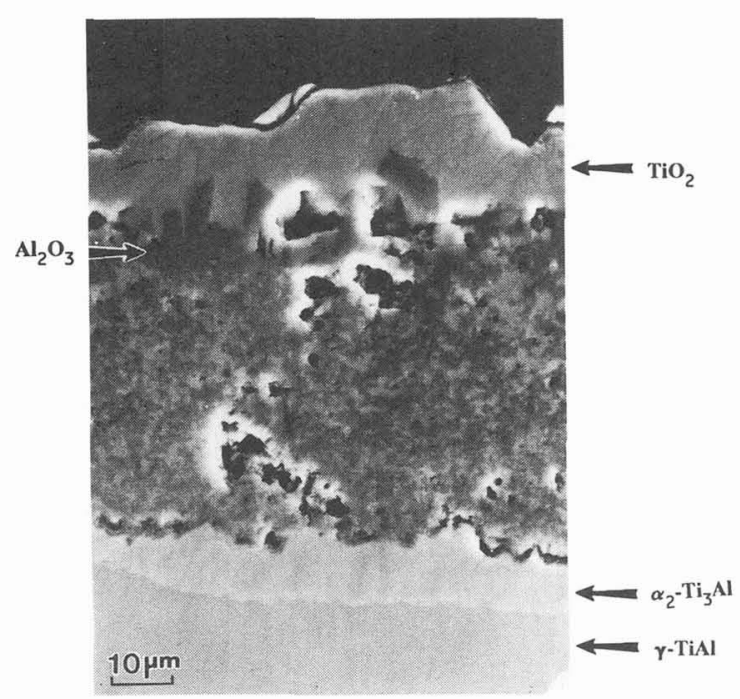

Fig. 5.

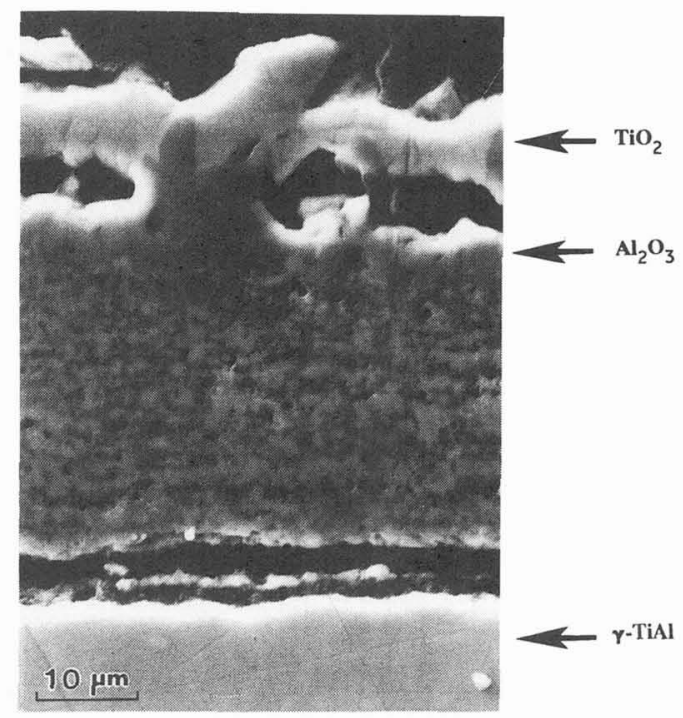

Fig. 6 .

Fig. 5. - Cross-section of TiAl (52 at\% Al) oxidized in $10 \% \mathrm{~N}_{2}-90 \% \mathrm{O}_{2}$ at $900{ }^{\circ} \mathrm{C}$ for 80 hours.

Fig. 6. - Cross-section of TiAl $(52$ at $\% \mathrm{Al})$ oxidized in air at $900^{\circ} \mathrm{C}$ for 80 hours. 


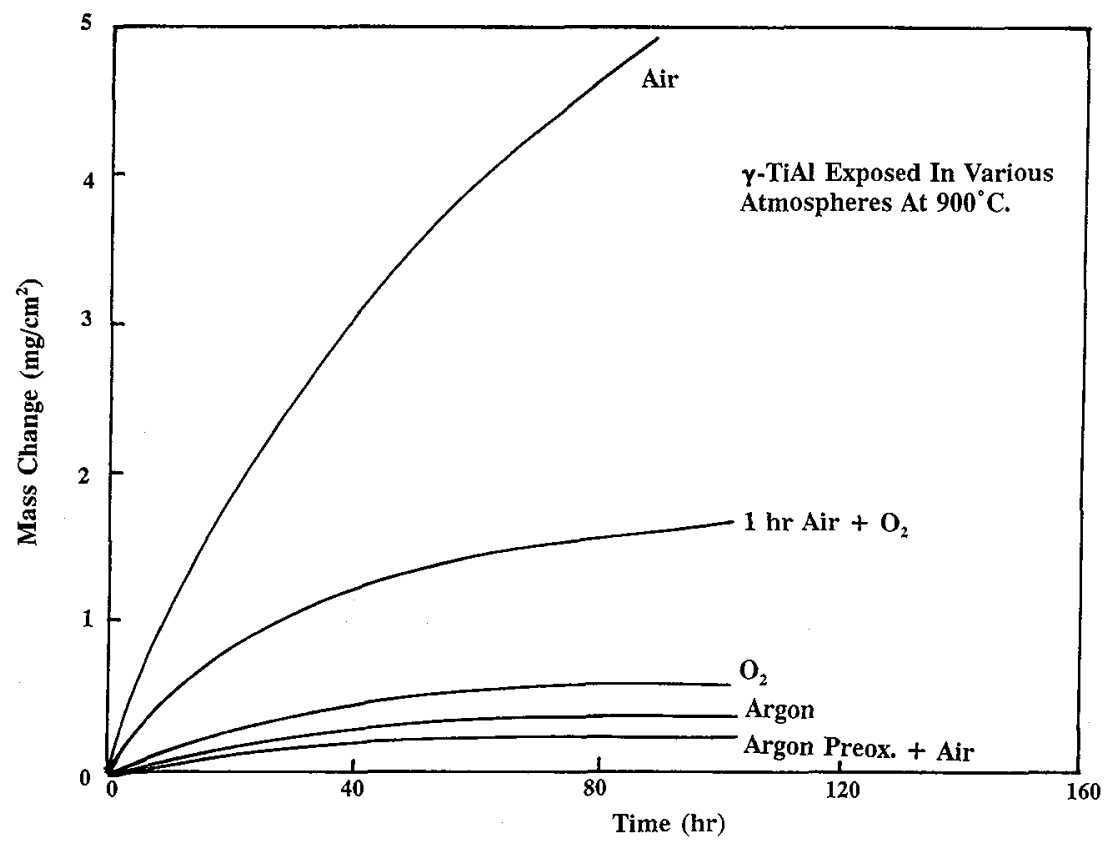

Fig. 7. - Weight change versus time curves showing the effect of various pretreatments on the oxidation behavior of $\mathrm{TiAl}(52 \mathrm{at} \% \mathrm{Al})$ at $900{ }^{\circ} \mathrm{C}$.

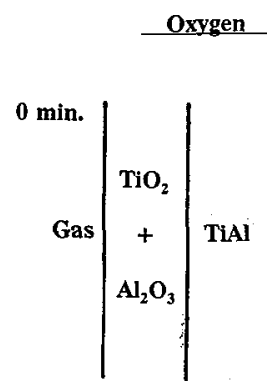

$\mathrm{Gas}\left|\begin{array}{c:c} & \\ \mathrm{TiO}_{2} & \\ + & \mathrm{O}^{\mathrm{m}} \\ \mathrm{Al}_{2} \mathrm{O}_{3} & \end{array}\right|$ TiAl
Air.
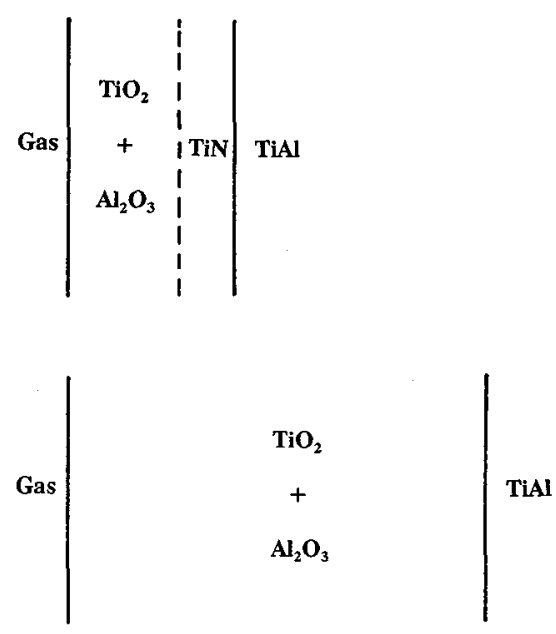

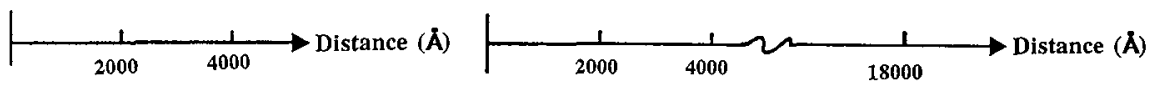

Fig. 8. - Summary of initial scale growth sequence on TiAl in air and oxygen inferred from Auger sputter profiles. 